\title{
Analyzing the Library Information of Semarang Special Education School
}

\author{
Rukiyah $^{1}$, Jazimatul Husna ${ }^{2}$, Girindra Putri Ardana Reswari ${ }^{3}$ \\ \{rukiyah50@yahooo.com, jazimatulhusna@lecturer.undip.ac.id, \\ girindra.reswari@live.undip.ac.id\}
}

\begin{abstract}
Indonesian Literature, Faculty of humanities, Diponegoro University, Indonesia ${ }^{1}$, Library and Information Department, Vocational School, Diponegoro University, Indonesia ${ }^{2}$, Department of Applied Foreign Language, Vocational School, Diponegoro University, Indonesia ${ }^{3}$
\end{abstract}

\begin{abstract}
This study aimed at analyzing information needed, efforts of the students with disability in fulfilling their information need, and to find out the obstacles experienced. The study uses a qualitative method by having 7 informants: students with disability, parents, and teacher of Special Education School in Semarang. The methods of data collection are observation, interview, and documentation. The data sources are obtained from a primary and secondary data source. By analysing the data based on Miles and Huberman, it is found that, 1) Varied efforts used by students in fulfilling the information needs. Most of the students tend to use the information from teacher, parents, friends and also use audiovisual media like information technology and television in fulfilling their information needs. 2) Different obstacles experienced by each student with disability in order to fulfill their information need. However, the common obstacles are reading, listening, speaking and physical accessibility orientation.
\end{abstract}

Keywords: The information need, Disability, School Library, State Special School of Semarang.

\section{Introduction}

Information is a record of observed phenomenon or decisions made for supporting policy making [1]. The information need is always attempted to be fulfilled. Recently, the fulfillment of the information needs for students without disability is quite easy. As students in general, students with disability require many kinds of information to fulfill their necessity of life. However, with their disability, they will face obstacles in order to fulfill their information needs.

The history of the thinking and attention development towards people with disability in Indonesia begun when the activists of disability introduced the term "disability" in 1998. It was aimed to replace the term of disabled people which was contextually discriminate. Therefore, the term of disability derived from English prose "different ability people" would be more concern to the differentiation of abilities, instead of defect or imperfection.

Furthermore, the Indonesia Government ratified the Convention on the Right of Person with Disabilities (CRPD) on October 2011 into Indonesia Law number 19 year 2011 about Convention on the Rights of Persons with Disabilities [2]. In the Indonesia Law number 19 year 2011 is mentioned that people with disability possesses the right to acquire respect for their mental and physical integrity based on the equality with others, including the rights to acquire protection and social services. 
It is hoped that the school library can help the students to obtain information about their necessity of life. The school library also should make a policy and a landing map that can provide guidance to store, collect books, mold materials and recording in particular. Therefore, the map can provide a school library in which every student has a right and chance to increase knowledge.

Most of the libraries in schools actually have not given proper facilities for students with disability. The existing libraries only provide old books and do not have a special service for students with disability. Therefore, this study is conducted to help the school library and the school itself in facilitating students with disability. Meanwhile, the reason why the study conducted is because of realizing the fact that people with disability has not been able to obtain information well. So far, the library does not have proper and accessible facilities, such as specific collections, service, and rooms with special design for people with disability. Based on the background above, the problem statements of the study are: (1) What is the kind of mapping information needs by the students with disability and how to fulfill the information needs of students with disability in the library of State Special School of Semarang? (2) What are the obstacles experienced by the students with disability in the library of State Special School of Semarang?

Meanwhile, the limitation of the study is the information needs required by the students with disability in the library of State Special School of Semarang which is reviewed based on the context of social environment, social roles and personal aspect or personal aspect, information sources, or media used in order to fulfill the information needs. Then, the obstacles which appear related to students with disability in fulfilling their information needs.

\section{Method}

Interview, observation and documentation study are the techniques used to conduct the study. The data source which is obtained from primary and secondary data source is analyzed using the analysis of Miles and Huberman. The research method will discover and provide data on what kind of information needed and also mapping or creating the flow of information needs of the students with disability.

\section{Results and Discussion}

\subsection{SLB Negeri Semarang}

State Special School of Semarang was officially opened since 2004. In order to increase the educational service for children with disability in Central Java Provincial Government, Departement of Education and Culture finally estabished Semarang Special Education School located at Jl. Elang Raya 2 Semarang. Based on the Regulation of Central Java Governor number 6 year 2005 Special School of Semarang became a unit of special education system in Central Java. State Special School of Semarang has some levels of education system such as, TKLB (Special School for Kindergarten), SDLB (Special School for Elementary School), SMPLB (Special School for Junior High School) and SMALB (Special School for Senior High school). State Special School of Semarang handles children with special needs, such as children with visual impairment, hearing impairment, speech impairment, intellectual disability, physical impairment, and autism. 


\subsection{The Condition of State Special School of Semarang's Library}

According to [3], there are four levels of information needs. They are visceral need which means actual but unexpressed information, conscious need which means explicable needs, formalized which means formal statement of the needs, and compromised which means the question which is presented to the information system. Taylor [4] stated that there are four kinds of needs toward information: (1) Current need approach is an approach intended to the user toward an up to date information; (2) The users need constant interaction towards the information system. Therefore, they can increase their knowledge; (3) Everyday need approach is a specific and fast approach toward the user needs in which the information is familiar with the user; (4) Exhaustic need approach is an approach toward the user needs in order to obtain deeper information. The users usually tend to have a high dependency towards relevant, specific and complete information; (5) Catching-up need approach is an approach intended to the users toward a brief and complete information, especially talking about the latest progress of a certain subject and relevant matters.

Based on the study, there are some library collection and facilities supporting the library. (1) The area of library's room of State Special School of Semarang is $117 \mathrm{~m}^{2}$ located on 2nd floor of Block B. It is in the same location with ITC (Information Center Technology) room which has 17 units of Personal Computer; (2) The library is recently managed by an officer working as a technology expert who had participated in library training. By the presence of library officer, hopefully the library supervision such as services, administration etc. can be more systematic and correspond with the applicable rules and the standard; (3) The library in State Special School of Semarang has the printed collection like books, magazines, textbooks, books for upgrading skills, newspaper and the unprinted collection like CD (Compact Disk), audio $\mathrm{CD}$, globe, and map. Those collections are completed with book tag, book card which had been arranged based on the DDC (Dewey Decimal Classification); (4) Every class is provided with mini-library to ease the students related to their mobility and also to decrease their dependency towards others. The mini-library was established based on the idea of visual impairment teacher in collaboration with the library officer. There are some collections of the mini-library, such as braille books and braille Al-Qur'an with approximately 90 copies, textbooks, $10 \mathrm{CDs}$ audio. There are also a certain cabinet to store paper and braille typewriters and a computer completed with JAWS.

\subsection{Mapping The Information Needs of Students with Disability in The Library of State Special School of Semarang}

Based on the research, the informants stated that the important information needs in the form of textbooks will give more benefits for their learning process. The benefits can be a raising of their standard of living, helping in teaching and learning process and also increasing a specific knowledge. However, the obstacles can come up when the government has not provided a standard and proper facilities for students with disability yet.

The informants also explained that information from textbooks is basic needs for students. The teaching and learning process is not only supported by the existence of textbooks but also the existence of special learning tools such as Stylus, Slate and JAWS Screen Reader. Stylus and Slate are tools used by person with visual impairment to write text and then read it without assistance and JAWS (Jacob Access With Speech) Screen Reader is a tool used by person with visual impairment to read a screen in computer. Then, students with disability also require a general information in the form of reading materials. 


\subsection{Reading Materials Supporting Need}

Reading materials have a purpose as an entertaining tool. For example, books which contain things out of lesson or newspaper using braille. [5] claimed that need is related to the individual itself. The informants stated that the individual characteristic is related to the fulfillment of cognitive factor, affective factor and the fulfillment in obtaining entertainment (escapist needs).

Affective needs is a need required to increase knowledge and information about surrounding in which obviously, each of the children has different characteristic. According to the librarian, there is a special magazine namely Gema Braille which was intended to students with disability. The obstacle in fulfilling the cognitive factor in State Special School of Semarang is the lack of textbooks availability, especially math textbooks in which math is one crucial and complex knowledge.

Therefore, it is very required in the learning process. Then, to fulfill the entertaining aspect, there is also found an obstacle. It is about how to produce content in multi-platform and single platform. In producing a content, multi-platform and single platform have different patterns.

Multi-platform involves the collaboration between divisions in every platform to share and reproduce the main content based on the uniqueness of every platform. The multiplatform worker must have a multitasking skill, like converting interview transcript into an initial script and then it is processed into audio or video content [6].

\subsection{Information Technology Supporting Needs}

Information technology is an important aspect in everyday life, especially when people use the internet to fulfill their needs. The informants explained that the existence of internet actually helps them in order to find information which supports the teaching and learning process. Yet there are some obstacles coming up toward this issue such as the lack of internet access. According to the librarian, the difficulties in accessing internet caused by some factors.

Then, as the function of learning process or entertaining facilities, information can be obtained through TV (television), radio, internet or even the chitchat or conversation happened in school. However, for students with visual impairment, it is kind of troublesome them because they can not see the object well.

The recommendation in the study is the use of a tool called "Talk". The tool can be used to decrease the limitedness and the lack of internet access when the students want to obtain information. Talk can be installed in students' mobile phone and it will help students in searching for information. The information not only about knowledge related to the lesson in school or teaching and learning process but also about basic information for everyday life.

Next, the accessibility toward convenient road access when the students want to go outside with or without control. Therefore, they can search for information about mobilization access through the organization they join. Actually, it can simplify them related to mobilization and decrease the dependencies toward others.

\section{Recreational and Accessible Supporting Needs}

The needs can support the recreational and informative means for example, the use of television by students disability in receiving information. Sometimes the students experience 
the obstacle because some students just can listen without seeing the reality of condition displayed on television.

Another example of entertainment aspect required by the students with disability in State Special School of Semarangis the information about music in which can increase their knowledge and reference toward their extracurricular (additional non-formal lesson), especially music group. Moreover, the information about technology and internet simplifying the students in finding and obtaining information or just playing and the information of fiction stories are also the examples of supporting needs required by the students in State Special School of Semarang.

However because of the facilities in State Special School of Semarang have not accessible yet, the students with disability can not access information based on their necessity easily. The example of some school facilities which have not accessible and acceptable yet such as an accessible sidewalk, means of recreational points, buildings, and school parks.

\section{References}

[1] Yusup, Pawit M. Pedoman Praktis Mencari Informasi. Bandung: PT Remaja Rosdakarya (1995).

[2] Husna, J.. Pustakawan dan Social Soft Skill Bagi Difabel. Yogyakarta: Cetta Media (2013).

[3] Taylor, R. S. Question Negotiation and Information Seeking in Libraries. College and Research Libraries, 29, 178-189 (1968).

[4] Erdal, Ivar John. Crossmedia News Journalism: Institutional, Proffesional, Textual Strategies and Practice in Multi-platform News Production. Ph.D Dissertation. University of Oslo (2008).

[5] Wilson, T. D. Human Information Behavior. Special Issue on Information Science Research, 3, 2 (2000).

[6] Farradane, J. The Nature of Information. Information Science, 1, 13-17 (1979). 